Volume 54, Issue 2 (Winter 2017)

Special Issue: Introduction to the Law and Markets:

Regulating Controversial Exchange

Article 2

Guest Editors: Kimberly Krawiec, Poonam Puri and

Mitu Gulati

\title{
From Baby-selling to Boilerplate: Reflections on the Limits of the Infrastructures of the Market
}

Margaret Jane Radin

University of Toronto

Follow this and additional works at: http:// digitalcommons.osgoode.yorku.ca/ohlj

Part of the Law Commons

Special Issue Article

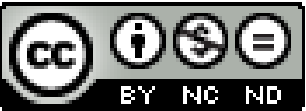

This work is licensed under a Creative Commons Attribution-Noncommercial-No Derivative Works 4.0 License.

\section{Citation Information}

Radin, Margaret Jane. "From Baby-selling to Boilerplate: Reflections on the Limits of the Infrastructures of the Market." Osgoode Hall Law Journal 54.2 (2017) : 339-376.

http://digitalcommons.osgoode.yorku.ca/ohlj/vol54/iss2/2

This Special Issue Article is brought to you for free and open access by the Journals at Osgoode Digital Commons. It has been accepted for inclusion in Osgoode Hall Law Journal by an authorized editor of Osgoode Digital Commons. 


\title{
From Baby-selling to Boilerplate: Reflections on the Limits of the Infrastructures of the Market
}

\begin{abstract}
Market-inalienability has a central place in developed societies that embrace private law institutions and a traditional understanding of the role of the polity in underwriting, managing, and preserving those institutions. Market-inalienability is a form of non-commodification. Taking up the issue of what things or relationships can be treated as commodities, I first critique a mode of inquiry - a traditional view of law and economics - that finds no problem with commodification of anything whatsoever. Counter to this mode of reasoning, I review two points of view that consider some kinds of commodification wrongful. Finding neither of these anti-commodification theories satisfactory, I review in some detail the example of baby-selling to show the dilemmas of commodification and the complexity of arguments about it. I then turn to the practice of standardized fine-print contracts ("boilerplate") that routinely waive the background legal rights of those who receive them. This practice of using contract to escape basic rights commodifies some rights that ought to be market-inalienable. Such rights should remain permanently in the care of the polity and should not be treated as objects of trade.
\end{abstract}

\section{Keywords}

Commodification; Personhood; Market-inalienability; Baby-selling; Boilerplate; Rule of law; Redress of grievances; Property; Contract

\section{Cover Page Footnote}

Thanks to the USC Center for Law, History and Culture, and special thanks to Center colleagues Nomi Stolzenberg, Hilary Schor, and Ariela Gross for inviting me to deliver this lecture, and for permitting me to publish portions of it in revised form in this article. 


\title{
339
}

\section{Special Issue}

\section{From Baby-selling to Boilerplate: Reflections on the Limits of the Infrastructures of the Market*}

\author{
MARGARET JANE RADIN ${ }^{+}$
}

Market-inalienability has a central place in developed societies that embrace private law institutions and a traditional understanding of the role of the polity in underwriting, managing, and preserving those institutions. Market-inalienability is a form of non-commodification. Taking up the issue of what things or relationships can be treated as commodities, I first critique a mode of inquiry-a traditional view of law and economics - that finds no problem with commodification of anything whatsoever. Counter to this mode of reasoning, I review two points of view that consider some kinds of commodification wrongful. Finding neither of these anti-commodification theories satisfactory, I review in some detail the example of baby-selling to show the dilemmas of commodification and the complexity of arguments about it. I then turn to the practice of standardized fine-print contracts ("boilerplate") that routinely waive the background legal rights of those who receive them. This practice of using contract to escape basic rights commodifies some rights that ought to be marketinalienable. Such rights should remain permanently in the care of the polity and should not be treated as objects of trade.

Key words: commodification, personhood, market-inalienability, baby-selling, boilerplate, rule of law, redress of grievances, property, contract

* An earlier version of this article was presented at the Law \& Markets: Regulating Controversial Exchange Symposium on 15 September 2015 at Osgoode Hall Law School, Toronto.

$+\quad$ Professor, University of Toronto Faculty of Law; Henry King Ransom Professor, emerita, University of Michigan Law School; William Benjamin Scott \& Luna M Scott Professor, emerita, Stanford University Law School. This article is derived from the Law and Humanities Lecture at the University of Southern California Law School in March, 2015. Thanks to the USC Center for Law, History and Culture, and special thanks to Center colleagues Nomi Stolzenberg, Hilary Schor, and Ariela Gross for inviting me to deliver this lecture, and for permitting me to publish portions of it in revised form in this article. 
Le concept d'inaliénabilité-marchande occupe une place centrale dans les sociétés développées qui se sont dotées d'institutions de droit privé et qui s'en tiennent à une conception classique du rôle de la politie dans la garantie, la gestion et la préservation de ces institutions. L'inaliénabilité-marchande est une forme de non-marchandisation. Dans l'optique de déterminer quelles choses ou quelles relations peuvent être traitées comme des marchandises, je commence par critiquer une méthode d'analyse fondée sur une conception traditionnelle du droit et de l'économie qui n'émet absolument aucune objection à l'égard de la marchandisation. À contre-courant de ce mode de raisonnement, j'entreprends d'examiner deux points de vue qui avancent que certains types de marchandisation sont injustes. Estimant qu'aucune de ces théories critiques à l'égard de la marchandisation n'est satisfaisante, je m'intéresse de près à l'exemple de la vente de bébés afin de montrer les dilemmes posés par la marchandisation et la complexité des arguments à ce sujet. Je me penche ensuite sur la pratique des contrats standardisés (ou « contrats types ») qui dérogent systématiquement aux droits juridiques de base des personnes à qui ils s'appliquent. Le recours aux contrats pour échapper aux droits fondamentaux revient à marchander certains droits qui devraient pourtant être inaliénables. Ces droits devraient rester en permanence sous la protection de la politie et ne devraient faire l'objet d'aucun commerce.

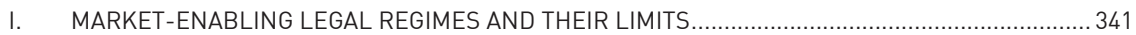

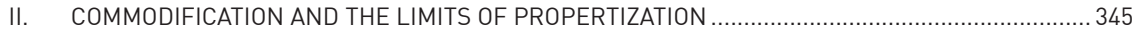

A. Market Rhetoric and Old-School Chicago............................................................... 345

B. Two Strands of Thought on the Commodification Puzzle ............................................ 349

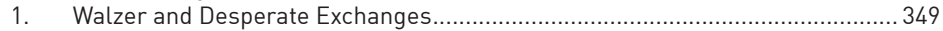

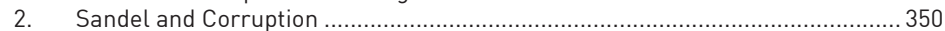

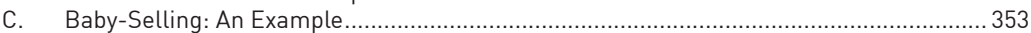

D. Further Comments on Contested Commodities..................................................... 357

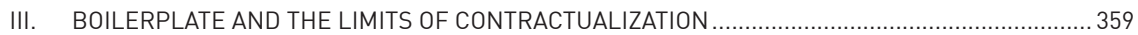

A. A Problem in Theory-to-World Fit...................................................................... 360

B. Other Approaches to Evaluation of Boilerplate Enforceability .................................... 363

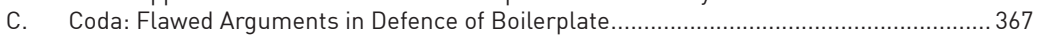

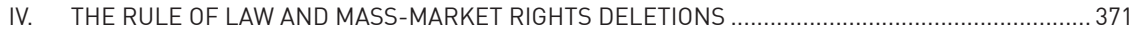

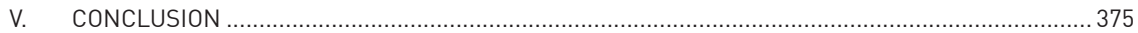

THIS ARTICLE REFLECTS ON MY PATHS AS A RESEARCHER; first in property law, and later in contract law. Each path led me to study the limits of these aspects of private law. Each path led to the issue of market-inalienability in theory and practice. In Part I, I consider the background limits of market-enabling legal regimes. In Part II, I critique a traditional view of law and economics that condones the commodification of anything whatsoever. Counter to this mode of reasoning, I review two points of view that consider some kinds of commodification wrongful: commodification as "desperate exchanges" and

1. Michael Walzer, Spheres of Justice: A Defense of Pluralism and Equality (New York: Basic Books, 1983) at 102. 
commodification as "corruption." Finding neither of these anti-commodification theories satisfactory, I review in some detail the example of baby-selling-which should more accurately be called purchased adoption-to show the dilemmas of commodification and the complexity of arguments about it.

Juxtaposing these forms of commodification to a variety of commodification that is more specifically thought of as contractual overreaching rather than property overreaching, I turn my attention in Part III to the commercial practice of deploying standardized fine-print contracts ("boilerplate") that routinely waive the background legal rights of those who receive them. This practice of using contract to escape basic rights commodifies some rights that ought to be market-inalienable. I argue that such rights should remain permanently in the care of the polity, and should not be treated as objects of trade. In Part IV, I consider the connection between the duties of the polity in this regard and maintenance of the Rule of Law. Part V concludes.

\section{MARKET-ENABLING LEGAL REGIMES AND THEIR LIMITS}

Markets depend upon an infrastructure of background rules or practices in order to function. Markets require enabling regimes. In developed societies, the background infrastructure consists primarily of the legal regimes of private law. But even informal markets need rules of the game. Without rules of the game, there may be anarchy, but not a functioning market. Those who argue that certain market limits or regulations interfere with the "free" market I take to be actually expressing a belief that the rules of the game of a particular market are not the proper ones. It is incoherent to suppose that a market—a legal social (or socio-legal) organized institution for trading entitlements—could be free of all rules whatsoever.

The primary legal regimes of private law are property and contract, which both govern the entitlements of, and transfer powers to, individuals or firms. Tort also is a part of private law, because it underlies private remedies, and (in traditional construals) is based upon individuals rights to be free of harm from others when the behaviour causing the harm is negligent or worse. Each branch of private law can be explained either on the basis of strictly individual rights, or on the basis of maintaining civil society and legality as a whole. In this article, I am concerned primarily with property and contract, their limits as between

2. Michael Sandel, What Money Can't Buy: The Moral Limits of Markets (New York: Farrar, Straus, and Giroux, 2012) at 46 [Sandel, What Money Can't Buy]. 
individuals or firms, and ultimately their relationship to the background state and the preservation of civil society and the Rule of Law.

Property law tells us with whom rights to control a resource start out, and contract tells us with whom those rights end up. I will often refer to "propertization" rather than to "property" simpliciter, to signify that what counts as property depends upon what a particular culture or state recognizes as property, and hence to signify that what is considered property changes over time as well as from place to place. Analogously, I will often refer to "contractualization" rather than to "contract" simpliciter, to signify that what counts as an enforceable contract varies over time and place.

Property and contract have limits. We often use certain symbolic examples to characterize those limits. In philosophy the idea of such a limit has often been characterized by considering selling oneself into slavery. If ownership of one person by another is not permitted, that is a limit on propertization. If trading a person to another is not permitted, that is a limit on contractualization. Another example often used to characterize limits on both propertization and contractualization is the sale of children. Baby-selling is disallowed-as many people tend to think at first glance- - both because babies are not to be considered as objects of propertization, nor are they to be considered objects of contractualization to be monetized and traded in markets. ${ }^{3}$ To come to the present real world, in the US many employees and consumers routinely receive fine-print alleged "contracts" that waive their background rights. This sort of fine-print mass-market rights deletion is known as boilerplate. Boilerplate prima facie raises questions about the limits of contractualization (are these lists of boilerplate terms properly considered contracts?) and, at a deeper level, issues of propertization (are these background rights appropriately considered property that individuals own and can dispose of in this manner?). In my work, I have gone from baby-selling to boilerplate-that is, from propertization to contractualization - but in both fields my overall focus has been on the limits of these private-law legal infrastructures. ${ }^{4}$

3. Baby-selling - more accurately labeled purchased adoption — became a case of contested commodification in recent years. See Part II(C), below, for further discussion on this topic.

4. See Margaret Jane Radin, Reinterpreting Property (Chicago: University of Chicago Press, 1993) [Radin, Reinterpreting Property] (essays on property, its rationales, and its limits); Margaret Jane Radin, Contested Commodities (Cambridge, Mass: Harvard University Press, 1996) [Radin, Contested Commodities] (the limits of the market); Margaret Jane Radin, Boilerplate (Princeton: Princeton University Press, 2013) [Radin, Boilerplate] (the limits of rights deletion by means of fine-print alleged contracts). 
One way to focus on the limits of propertization and contractualization is to focus on the lack of connection between rationales and practices. Let me call this the issue of theory-to-world "fit" (or lack thereof). To what extent must a theory offered to justify a practice fit the facts in practice in order to be accepted as a valid justification? I cannot answer this question in general terms. Instead, I argue that whatever level of fit is necessary to consider a practice justified, some practices can be seen not to rise to that level. If it seems that a particular justificatory theory could not reasonably justify a particular practice in the world, I call that a "disconnect" between the rationale and the practice.

A classical rationale for propertization is the idea that property is connected to fostering or enabling personhood. ${ }^{5}$ A classical rationale for contractualization"freedom of contract"-is the idea that contract is connected to fostering or enabling freedom. ${ }^{6}$ One can rely on Kant and Hegel for exegesis both of the personhood rationale for property and the freedom rationale for contract. ${ }^{7}$ Ultimately, freedom and personhood are connected in these theories.

These classic rationales underlie our received justifications for the private law institutions of the liberal state. It is true that these rationales have for some time (especially in the US) been overtaken by utilitarian ideas, and have for some time (especially among academics) been critiqued as liberal legalism. ${ }^{8}$ Below I will consider the position reached by a particular branch of utilitarian thought. Yet the classic rationales based on personhood and freedom remain significantly embedded in law, and in justification of the law in practice. All but the staunchest utilitarians or critical theorists still rely on them. Legal actors in practice ultimately rely on these classic rationales when they rely on the law as it has been handed down to them.

In what ways do accepted rationales not fit our practices? Utilitarianism, although widely prevalent in the US, does not fit well because it assumes commensurability and with it commodification (more on this issue in Section

5. Radin, Reinterpreting Property, supra note 4. I took up this rationale in an early article and reprinted it in this book, with a few corrections. See Margaret Jane Radin, "Property and Personhood” (1982) 34:5 Stan L Rev 957 (see also the introductory essay in this book, revisiting my earlier thoughts and replying to critics).

6. I offer a précis of various contract theories in Radin, Boilerplate, supra note 4 at 55-81.

7. Immanuel Kant, Moral Law: Groundwork of the Metaphysics of Morals, translated by H J Paton (London; New York: Routledge, 1948); Georg Wilhelm Friedrich Hegel, Phenomenology of Spirit, translated by A V Miller (Delhi: Motilal Banarsidass Publishers, 1998).

8. See e.g. Wendy Brown \& Janet Halley, eds, Left Liberalism/Left Critique (Durham: Duke University Press, 2002). 
C of Part II, below). Second, the personhood justification does not fit well because its deployment has been both overbroad and underinclusive in practice. As an example of the former, consider the distinction between personal and fungible property. When property is fungible it is used just like money; one property item just as good as another of the same dollar value. As Bentham is supposed to have said, "push-pin is as good as poetry." The personhood justification should at least prima facie apply only to a small subset of property rights in liberal society, not to the vast range of rights that are fungible among actors for whom dollar value is what matters. By contrast, when the personhood justification should apply, because an item of property seems clearly personal to its holder, this connection is sometimes just ignored. This is the widely held intuition about the famous case in Oklahoma in which farmer land-owners agreed to allow strip mining on their farm but bargained specifically for a clause promising that the company would restore the land; instead the court changed this property rule into a liability rule and gave the farmers only a pittance in money damages. ${ }^{10}$ These concerns give rise to further questions: since one of the main indicia of fungible property is tradeability for money and the concomitant commitment to monetary value, under what circumstances might money valuation be disallowed and personal property be transferable only by non-monetary transactions? In these cases, attributing money value amounts to wrongful contractualization. Then what are the limits of personal property? That is, what is wrongly propertized because it should be considered an attribute of persons and not propertized at all? These questions lead us to consider the issue of commodification.

9. Bentham said, "Prejudice aside, the game of push-pin is of equal value with the arts and sciences of music and poetry." See Jeremy Bentham, The Rationale of Reward (London: J and HL Hunt, 1825) at 206. The popular misquotation originated with John Stuart Mill. See John Stuart Mill, "Bentham," in Dissertations and Discussions: Political, Philosophical, and Historical: Reprinted Chiefly from the Edinburgh and Westminster Reviews, 2nd ed, vol 1 (London: Longmans, Green, Reader and Dyer, 1867) at 389.

10. Peevyhouse v Garland Coal \& Mining Co, 382 P (2d) 109 (Okl 1962). The terminology "property rule" and "liability rule" stems from a law review article by Guido Calabresi and A Douglas Melamed. A "property rule" means that owners have the power to decide whether or not to sell their entitlements, and to determine the price if they decide to sell. A "liability rule" means that another entity can divest the owner of the entitlement if it pays compensation determined by itself, not the owner. Calabresi and Melamed were thinking of forced divestment by courts and administrative agencies — for example, the power of eminent domain. See Guido Calabresi \& A Douglas Melamed, "Property Rules Liability Rules, and Inalienability: One View of the Cathedral” (1972) 85:6 Harv L Rev 1089 [Calabresi \& Melamed, "Property Rules, Liability Rules"]. 


\section{COMMODIFICATION AND THE LIMITS OF PROPERTIZATION}

Considering when contractualization and propertization are wrongful brings out an important way to focus on the limits of propertization and contractualization, namely, to consider their connection with commodification. A commodity is something traded in markets for money or whose value is understood in terms of money. Commodification, then, refers to the notion of treating something of value in terms of market value, most often with the connotation that that thing should not be so treated. As my research focused first on property and only later on contract, I begin here with property.

\section{A. MARKET RHETORIC AND OLD-SCHOOL CHICAGO}

To launch this discussion, I will recall the characteristic discourse of commodification, which I have called market rhetoric: In this discourse, everything valuable is treated as genuinely, perspicuously characterizable in terms of money and market exchange. Those who do not accept market rhetoric will consider it a form of reductionism in which all values are reduced to market value. But those who do accept market rhetoric will reply in market terms, saying that I value more highly my discourse of different kinds of values. Those who espouse market rhetoric are certain that we can and should analyze all human interactions in terms of market exchange. We are to understand use of this discourse and its reasoning as rationality. In a sense, market rhetoric has been the furthest reach of the utilitarian understandings of personhood and agreement in the context of a market society.

Let me recall some samples of market rhetoric and the discourse of commodification. In his work, $A$ Treatise on the Family, Gary Becker writes: "the demand for children would depend on the relative price of children ... . An increase in the price of children ... reduces the demand for children and increases the demand for other commodities (if real income is held constant)."11 In Sex and Reason, Richard Posner notes: "A polygamist, or for that matter the father of a girl, might tumble to the idea that a wife whose clitoris was removed would require less supervision by her husband. Such women would become more valuable in the marriage market. ..."12

11. A Treatise on the Family, 2nd ed (London: Harvard University Press, 1992) at 138.

12. Sex and Reason (Cambridge, Mass: Harvard University Press, 1992) at 214. 
As may be already clear, this market rhetoric discourse had its particular home in what I call "old-school Chicago law and economics." In spite of its location in Chicago, it spread throughout American legal scholarship during the last part of the twentieth century and perhaps the first decade of the twenty-first. ${ }^{13}$

The general background assumptions and conceptual commitments of old school Chicago law and economics are as follows: the goal of society is thought of in terms of welfare maximization (rather than human flourishing); government is thought of in terms of paternalism (rather than polity); and all values are thought of as commensurable and fungible, such that they can be arrayed on a scale and traded off against one another. Those who accept this approach also share a commitment to a particular conception of rationality, which holds that individuals are rational in that they maximize their own welfare, defined only by themselves. Individual rationality in this sense is combined with a broader methodological individualism, which holds that only summation of individual preferences is relevant for calculation of social welfare. Thus, there is no fundamental distinction between individual decision making and democratic ordering, which is conceived of as a congeries of individual maximizers cooperating for individual gain. ${ }^{14}$

In addition to these commitments to welfare maximization, commensurability, fungibility, methodological individualism, and rationality, several other tendencies seem to tag along with old-school Chicago commitments: a certain Manichean view (a tendency to consider everything as separable into two opposite poles or two opposing conceptual boxes); a certain Panglossian status quo bias (a tendency to consider that whatever is, is right-i.e., efficient and welfare-maximizing —at least presumptively); a certain foundationalism (a tendency to consider that reasoning should proceed from certain defined or root foundational premises such as efficiency, commensurability, methodological individualism, and rationality); a certain collapse of the public into the private (government regulation is justified, if at all, by finding a collective action problem rather than thinking about the Rule of Law, the commitments of civil society, or the functions that are inherent to polity); and a certain intuitive mapping

13. For my take on the premises and characteristics of "old-school Chicago," see Margaret Jane Radin, "Of Priors and Disconnects" (2014) 127 Harv L Rev F 259 (reply to review by Michelle Boardman).

14. See e.g. Richard A Posner, Economic Analysis of Law, 9th ed (New York: Wolters Kluwer Law \& Business, 2014); Robert Cooter \& Thomas Ulen, Law and Economics, 5th ed (Boston: Pearson/Addison Wesley, 2011); Dennis C Mueller, Public Choice III, (Cambridge: Cambridge University Press, 2003); James M Buchanan, Politics as Public Choice (Collected Works of James M. Buchanan, The), vol 13 (Illinois: Liberty Fund, 2000). 
of these premises onto human behaviour (human choices are seen as "trades" or "tradeoffs"). ${ }^{15}$

At the high point of the market rhetoric discourse that reflected these basic assumptions, self-interested profit-maximizing was defined as "rationality." "Rational choice theory," for example, referred to a theory dealing with how people choose whatever will maximize achievement of the value they self-interestedly pursue. This theory need not worry about the sale of children for adoptionbecause everything about how we value children is already understandable in terms of monetization. So Richard Posner, now a celebrated American judge, probably did not think it was odd to publish an article in the 1970s suggesting a market in the adoption of children. ${ }^{16}$

Along related lines, practitioners of economic political theory-also known as positive political theory or public choice theory-are not worried about turning democracy into a commodified enterprise, because in their analysis it already is exactly that. We are to imagine a firm as asking itself the following species of questions, to be decided by cost-effectiveness: "Shall we purchase legislation in our favour?"; "Shall we purchase legislators (i.e., bribe them with large donations)?"; "Shall we combine with other firms to impose our scheme?"; "Shall we use onerous mass-market boilerplate-so-called adhesion contractsto withdraw background legal rights of consumers?"

Contemporary psychological insight into human decision making has begun to undermine this view of human beings in terms of market rhetoric and commodification. The field of behavioural economics-including behavioural law and economics-is coming into maturity, and some former practitioners of rational choice theory are in the process of reconsidering their foundational commitment. Daniel Kahneman's book, Thinking, Fast and Slow, recounting his body of work with Amos Tversky, amounts to a renunciation of the "rational" conception of human beings and their values in market rhetoric. As Kahneman said, "To a psychologist, it is self-evident that people are neither fully rational nor completely selfish." ${ }^{17}$ The behavioural economist Richard Thaler characterizes the distinction by calling the mythical person of economic theory an "Econ," whereas real humans are "Humans." 18

15. Radin, Contested Commodities, supra note 4 at 13.

16. Elisabeth M Landes \& Richard A Posner, "The Economics of the Baby Shortage" (1978) 7 J Legal Stud 323.

17. Thinking, Fast and Slow (Random House Canada, 2011) at 269.

18. See Richard H Thaler, Misbehaving: The Making of Behavioral Economics (New York: W W Norton \& Company, 2015). This conceit was popularized in the book Thaler co-authored with Cass Sunstein. See Richard H Thaler \& Cass R Sunstein, Nudge: Improving Decisions and About Health, Wealth, and Happiness, rev ed (New York: Penguin, 2009). 
What is the difference between Humans and Econs? Econs are "rational." Econs are also radical commensuralists. They believe that all things of value can be measured in one metric and can be traded off against one another to arrive at the best sum of value. The Econ single metric has been dollar-value for the true believers in old-school Chicago law and economics. Humans maintain a savings account at $1 \%$ interest while carrying credit card debt at $8 \%$. Econs-like an accountant in the sky-zero out the balance sheet. Humans weigh possible losses more heavily than hoped-for gains, whereas Econs treat these as the same. So, Econs write off sunk costs, but Humans throw good money after bad.

Hilary Putnam, in his 1981 book, Reason, Truth, and History, offered a striking parable regarding an imaginary group of humanoid "Super-Benthamites" and how they differ from humans. ${ }^{19}$ This parable raises the issue of commodification: How much (or how little) that characterizes humans and their choices can be captured in the old-school Chicago type of thought? Further, might true belief in this model, if implemented fully in life and society, undermine our humanity? To raise the question about commodification it is now more succinct to characterize it as a worry that pervasive commodification could turn Humans into Econs. An old-style Chicago economics theorist—such as Becker or Posner in the 70s and 80s-would say we have no worries because we are already Econs (if these theorists thought we were not fully Econs, at least they must have thought we were close enough to being Econs to make their theories worth considering). Firms, too, are Econs. That is why these theorists tend to reduce the polity to a congeries of individual Econs, and why they tend to consider political reasoning and decision making as identical to cost-benefit analysis.

For those of us who do not accept the premises of old-school Chicago economics (including, I believe, some writers who formerly were but no longer are true believers), the question about the limits of commodification-and therefore the limits of propertization and contractualization-becomes how to differentiate convincingly between situations in which markets are appropriately permitted from those in which they are not. This question has remained a puzzle. We could phrase it as the monetization versus non-monetization of things, people, attributes, groups, commitments—whatever we Humans value.

19. Reason, Truth and History (Cambridge, Mass: Cambridge University Press, 1981) at 139-41. 


\section{B. TWO STRANDS OF THOUGHT ON THE COMMODIFICATION PUZZLE}

Rather than review the substantial literature on commodification and its limits, I will recall here two important strands of thought. ${ }^{20}$ One of them, discussed by Michael Walzer in his 1983 book, Spheres of Justice, ${ }^{21}$ can be aligned with efforts to police contractualization for contracts that are not the result of free choice. The other, advanced by Michael Sandel in his 1998 Tanner Lectures and later popularized in his 2012 book, ${ }^{22}$ can be aligned with efforts to police propertization to prevent treatment of certain things as commodities in markets.

\section{WALZER AND DESPERATE EXCHANGES}

Walzer posits eleven separate spheres of justice, with the market as only one of them ("the sphere of money and commodities"23). Walzer's separation thesis is that justice consists in complex equality, by which he means that the existence of hierarchies in each sphere as a result of differences in biological endowments, energy, and luck, is not wrong so long as preeminence in one realm does not spill over, giving the top dogs in one realm automatic dominance in others. In other words, justice consists in keeping the spheres separate. This thesis may seem to imply that complete commodification in the market sphere is acceptable so long as the market sphere is delineated properly.

Among the other spheres are education, free time, security, recognition, public office, and political power. The question arises how to prevent money and power in the market sphere from spilling over and giving those who dominate the market unjust dominance in the other spheres? Walzer's answer was that "the most important principle has this (rough) form: the exercise of power belongs to the sphere of politics, while what goes on in the market should at least approximate an exchange between equals (a free exchange)." ${ }^{24}$

Walzer's argument is unsatisfactory because his distinction between market liberty and personal liberty assumes the divide Walzer wants the distinction to

20. For more literature, see Radin, Contested Commodities, supra note 4. See also Elizabeth Anderson, Value in Ethics and Economics (Cambridge, Mass: Harvard University Press, 1993); Martha Nussbaum, Women and Human Development: The Capabilities Approach (Cambridge, UK: Cambridge University Press, 2000).

21. Walzer, supra note 1.

22. "What Money Can't Buy: The Moral Limits of Markets" (The Tanner Lectures on Human Values, delivered at Brasenose College, Oxford, 11-12 May 1998), online: <tannerlectures. utah.edu/_documents/a-to-z/s/sandel100.pdf> [Sandel, Tanner Lectures]; Sandel, What Money Can't Buy, supra note 2.

23. Walzer, supra note 1 at 120.

24. Ibid at 120 . 
delineate. Market liberty for Walzer characterizes the permissible domain of commodification, and personal liberty characterizes a domain that is off limits to the market. If we think that the kind of liberty to which an asserted transaction belongs is intuitively obvious or a matter of definition - or a matter of superficial conventionalism that we could determine by taking a survey-then we have solved the normative issue of the limits of the sphere of money and commodities. Otherwise, the categories of personal liberty and market liberty should be the conclusions of a moral argument rather than the basis of one. (To be fair to Walzer, I add that his main concern was to break down the issue of dominance in the cultural, historical condition in which we find ourselves, not necessarily to advance a method of solving such dilemmas. His intention was, it seems, primarily to develop a sociological analysis, not a moral one.)

In any event, by using the metaphor of spheres, Walzer does not advance a method of distinguishing between market liberty and personal liberty. It is unclear whether the distinction between "free exchange" and "exercise of power" (or, in Walzer's term, "desperate exchanges" ${ }^{25}$ ) is useful in delineating the market sphere. Does it mean we should allow only well-off people to sell their kidneys? Does it mean we should declare that poor people cannot enter into enforceable contracts? Such questions seem to be unanswered by resort to the metaphor of spheres. Moreover, Walzer's worst problem might be this: Even if we think of an exchange as coerced and not usefully characterized as an exercise of liberty, we are still left with the problem that, to desperate people, desperate exchanges must have appeared better than their previous straits, and in banning the exchanges we have not done anything about the straits. It seems to add insult to injury to ban desperate exchanges by deeming them coerced by terrible circumstances, without changing the circumstances.

\section{SANDEL AND CORRUPTION}

In his Tanner Lectures of 1998, Michael Sandel distances himself from "the argument from coercion" - that is, from those who think that commodification (and privatization of public life) can be addressed simply by adjusting the background conditions within which market trades operate. ${ }^{26}$ Sandel also distances himself from the idea of fairness in background conditions, ${ }^{27}$ which

25. Ibid at 102.

26. Sandel, Tanner Lectures, supra note 22 at 94 .

27. "The argument from corruption is intrinsic in the sense that it cannot be met by fixing the background conditions within which market exchanges take place. It applies under conditions of equality and inequality alike" (ibid at 95). 
he allies with the idea of consent, that is, properly implemented freedom of contract. Here he parts company with the implications of Walzer's argument. Free and equal exchanges are not enough; that is, properly implemented contractualization is not enough. "What that argument misses," he writes, "are the dimensions of life that lie beyond consent, in the moral and civic goods that markets do not honor and money cannot buy." ${ }^{28}$ So Sandel turns instead to the concept of corruption. There are things that monetization corrupts, he says, and we have to find out what things those are. I remain unclear about how exactly, and on what principles, Sandel means to do that. ${ }^{29}$

I agree with the idea that more than free and equal contract ("fair exchange") is needed for a satisfactory understanding of the limits of commodification. But Sandel's argument against addressing background conditions seems to exclude a significant pragmatic position allied with lack of fair terms of social cooperation. If everyone's choices to buy and sell were truly voluntary, it seems we would have a lot fewer sales of babies, kidneys, and sexual services. Rich consenting people are not observed selling their children or kidneys; they are observed buying the children or kidneys of poor people. Rich consenting people are not observed entering sex work; they are observed buying the sexual services of poor people. This inequality raises the possibility that commodification is only worrisome to us (if we are not old-school Chicago economics believers, who do not worry about commodification) because the social conditions of trade are themselves worrisome. It is not so easy to dismiss the issue of fair background conditions. In a hypothetical world of complete freedom of choice, which is so far from our own, can we even say anything about commodification? Perhaps an ideal complete consent world would not use capitalist competitive markets. Full contractual consent and fully free private ordering is ideological, not characteristic of any real market society.

Also significant in my view is the fact that Sandel's argument seems to skirt the possibility that privatization of public life should be treated as a separate topic from commodification in private markets. Excessive privatization of public life means (in my formulation) removing to the private sphere aspects of social life, control, and democratic ordering that belong to the polity only. Consider private

28. Ibid at 122. See also Sandel, What Money Can't Buy, supra note 2 at 203 ("Do we want a society where everything is up for sale? Or are there certain moral and civic goods that markets do not honor and money cannot buy?”).

29. Sandel, What Money Can't Buy, supra note 2 at 46. "[W] corrupt a good, an activity, or a social practice whenever we treat it according to a lower norm than is appropriate to it." ... A deal, even if not coercive, is corrupt when both parties "value the good being sold ... in the wrong way" (ibid). 
prisons, private police forces, private armies: such privatization of public functions may seem to be instances of commodification but they also significantly threaten the Rule of Law because they represent a degradation of democracy. ${ }^{30}$ Excessive privatization is degrading or corrupting for democracy, but not in the same way as commodification in individual transactions (though often they can occur together). Excessive privatization degrades democracy because the background safeguards of the polity are eliminated: private police, private armies, and private prisons are not subject to constitutional limits on their power. They make more profit when the situation for people in their purview gets worse, so they are incentivized wrongly and in a way that undermines the democratic polity's equal concern and respect for its members.

How are we to decide when a type of transaction is corrupt, according to Sandel? As Sandel recognizes, the argument that commodification corrupts or degrades certain goods raises the difficulty that the argument from corruption has to be made in a different way, case by case: "It must be shown how, in each case, market valuation and exchange degrades or corrupts important values or ends that non-market practices may embody." ${ }^{31}$

Sandel also notes another difficulty with his view:

If we derive the fitting or proper way of regarding goods from the social meanings that prevail in a given society at a given time, we run the risk of lapsing into conventionalism. If, for example, there are fewer and fewer things that money

30. Margaret Jane Radin, "Boilerplate: A Threat to the Rule of Law?" in Lisa M Austin \& Dennis Klimchuk, eds, Private Law and the Rule of Law (New York: Oxford University Press, 2014) 288 at 300 [Radin, "A Threat to the Rule of Law"]. Excessive privatization of the aspects of democratic ordering that rely on the functional legal infrastructure presupposed by the idea of commitment to the Rule of Law, such as access to courts and constitutional limitations on the activities of police, results in a degradation of democratic ordering. In a functioning democratic ordering, redress of grievances is available to all, and the activities of entities such as police are subject to the same rules for the benefit of every one, and not dependent on the "private" profits of the market. The closest Sandel comes to considering democratic degradation in his book is this passage: "In addition to debating the meaning of this or that good, we also need to ask a bigger question, about the kind of society in which we wish to live. ... At a time of rising inequality, the marketization of everything means that people of affluence and people of modest means lead increasingly separate lives. ... Democracy does not require perfect equality, but it does require that citizens share a common life. ... For this is how we learn to negotiate and abide our differences, and how we come to care for the common good" (Sandel, What Money Can't Buy, supra note 2 at 202-03). I will come back to democratic degradation and the Rule of Law in Part IV, below.

31. Sandel, Tanner Lectures, supra note 22 at 106. See also ibid at 104: "The argument from corruption will be different in each case ... the argument from corruption appeals to the character of the particular good in question." For further discussion, see Part II(D), below. 
cannot buy these days, we might simply conclude that the meaning of our social practices is changing in this respect. ... If, however, we derive the fitting or proper way of regarding goods from some notion of the essential nature of the practices in questions, we run the risk of essentialism - the idea that the purposes and ends of social practices are fixed by nature. ${ }^{32}$

This is indeed a serious difficulty. Is it possible to argue that markets corrupt or degrade certain goods, without lapsing into conventionalism or essentialism? In my opinion, it is hard to do that without turning to a pragmatically inflected Aristotelianism, which would try to hold to intrinsic values that characterize human flourishing while yet taking account of situations in our ever-changing various imperfect practices. Human flourishing is a deeply contested concept, and I cannot see how it will ever be otherwise. Sandel would perhaps dispute my inference about what he means by corruption by arguing that he does have a conception of human flourishing, just one that is different from mine.

Nevertheless, in my opinion, Sandel does fall off the horns of the dilemma on the side of conventionalism. He appeals again and again for us simply to see that bribery and sale of places in line, and so forth, are corrupt. It seems to me that unless we have an understanding of human flourishing to back up what we call corruption, ultimately corruption is a conclusory label for something we dislike, find distasteful, or abhor, given our current religious, social, and ethical culture.

Just who are "we"? The questions involving "our" conception of human flourishing and how it reads on whether or not markets are permitted in specific instances pose many difficulties. What counts as "our" in a multicultural society, and in a world of other societies? Another question, and one that has interested me in earlier work, is whether we can in some situations be Humans and Econs simultaneously. ${ }^{33}$ It does not seem difficult for us to think of a precious heirloom or a wedding ring as special and priceless "personal property" and yet have it appraised for insurance like an ordinary commodity. But could we maintain an organized market for adoption of children and yet maintain a non-commodified conception of children? Some say yes and others say no.

\section{BABY-SELLING: AN EXAMPLE}

To see some of the complexities in thinking about commodification and the limits of propertization and contractualization, consider the example of selling adoption. Although this topic is usually brought up as sale of children,

32. Ibid at 106 .

33. See Radin, Contested Commodities, supra note 4 (but in that book I had not yet come across Thaler's apt characterization of Humans versus Econs). 
it is actually narrower than the sale of children in general. Adoption, even if commodified, seems prima facie different from selling children as prostitutes or sex slaves or selling children to appear in pornographic films. So "baby-selling" is too gross a term for the complicated problem of sale of adoption. Nevertheless, I ask indulgence to keep referring to baby-selling, because at least it portrays the passion with which partisans of different commitments view this general topic.

The fact that commodified adoption is a narrower category than baby-selling brings up the troublesome question: What is the "good" that is the contested commodity for analysis? I believe that this kind of question will always plague Sandel's arguments. He realizes that each "good" must be considered separately in assessing corruption, but he does not tell us how we can define that "good." Even sale of adoption should—one can argue plausibly—be broken down for analysis into sale of children already born and those yet to be born. Sale of those yet to be born involves commissioned pregnancy-sale of children who are conceived to order. One can also argue plausibly that commissioned adoption should be further broken down by asking whether it matters if genetic material is contributed by one or both purchasers. Is or is not the practice of surrogacy merely a sub-category of commissioned adoption?

In previous work, ${ }^{34} \mathrm{I}$ laid out the main arguments for and against baby-selling. That exercise showed both that these arguments depend on definitions of the "good" in question, and that they do not line up with entrenched fault lines such as right and left or feminist and non-feminist. I think the exercise is worth recapitulating, so Tables 1-3 summarize the three types of arguments used in debates about the commodification of procreation or children. Each argument type relies on a different primary animating value, and for each animating value, there are arguments both for and against markets.

34. Margaret Jane Radin, "What, if Anything, Is Wrong with Baby Selling?” (1994-1995) 26:2 Pac LJ 135. 


\begin{tabular}{|c|c|c|c|}
\hline \multicolumn{4}{|c|}{ TABLE 1: LIBERTY OF PERSONS IN A MARKET SOCIETY35 } \\
\hline $\begin{array}{l}\text { Basic } \\
\text { Value }\end{array}$ & Branch & $\begin{array}{c}\text { Market Proponents' } \\
\text { Argument }\end{array}$ & $\begin{array}{c}\text { Market Opponents' } \\
\text { Argument }\end{array}$ \\
\hline \multirow{3}{*}{$\begin{array}{l}\text { Liberty of } \\
\text { persons in } \\
\text { a market } \\
\text { society }\end{array}$} & $\begin{array}{c}\text { A. Various } \\
\text { strands of } \\
\text { libertarianism }\end{array}$ & $\begin{array}{l}\text { Old-school Chicago } \\
\text { economists: Everything can be } \\
\text { understood in market terms; no } \\
\text { markets should be foreclosed or } \\
\text { regulated unless there is some } \\
\text { kind of market failure. }\end{array}$ & $\begin{array}{l}\text { Non-Chicago libertarians: Not } \\
\text { everything can be understood } \\
\text { in market terms; freedom of } \\
\text { the person is diminished, not } \\
\text { enhanced, if things "internal" } \\
\text { to the person are sold off, and } \\
\text { reproductive capacity is internal } \\
\text { in this sense. }\end{array}$ \\
\hline & B. Feminism & $\begin{array}{l}\text { Feminist liberationists: } \\
\text { Women themselves, not the } \\
\text { government, should be able } \\
\text { to decide whether or not to } \\
\text { sell their children, just as } \\
\text { they should be free to decide } \\
\text { whether or not to terminate a } \\
\text { pregnancy. }\end{array}$ & $\begin{array}{l}\text { Feminist historical critics: } \\
\text { Women's freedom is not } \\
\text { enhanced by reinforcing their } \\
\text { image as breeders (or providers } \\
\text { of sexual and reproductive } \\
\text { services), in light of the long } \\
\text { and sad history of gender roles. }\end{array}$ \\
\hline & $\begin{array}{c}\text { C. Results for } \\
\text { freedom in } \\
\text { practice }\end{array}$ & $\begin{array}{l}\text { Pragmatic economists: If the } \\
\text { market is not allowed, there } \\
\text { will be a black market, which } \\
\text { will be (is) much worse. This } \\
\text { argument reflects an idea about } \\
\text { the irrepressibility of money } \\
\text { where there is desire-e.g., } \\
\text { gambling, drugs, alcohol, } \\
\text { prostitution, and politics. } \\
\text { According to this argument, } \\
\text { the Econ in us is winning and } \\
\text { we should give up the fight. }\end{array}$ & $\begin{array}{l}\text { Idealistic progressives: If a } \\
\text { legal market is allowed, we will } \\
\text { never be able to return to a } \\
\text { non-commodified conception } \\
\text { of children, and thereby of } \\
\text { ourselves. In the US, and } \\
\text { perhaps in other countries, the } \\
\text { Econ seems to be stronger in } \\
\text { our political leaders and their } \\
\text { decision making than it is for } \\
\text { the populace as a whole. It } \\
\text { is better to take steps now to } \\
\text { overcome this imbalance while } \\
\text { we still can. }\end{array}$ \\
\hline
\end{tabular}

35. The organization of these arguments into the format of tables was suggested by Stepan Wood, the Editor-in-Chief of the Osgoode Hall Law Journal, and Tables 1, 2, and 3 were designed by Mr. Wood, with the author's approval and thanks. 


\section{TABLE 2: PROCREATION AS AN ASPECT OF HUMAN AUTONOMY OR SELFHOOD}

\section{Basic Value}

Procreation as a deep desire or aspect of human autonomy and self-hood (or human partnership)

\section{Market Proponents' Argument}

Those who are unfortunate enough to be infertile should be able to purchase what they need for fulfillment of their autonomy (and family formation or communality).

There is no evidence that these people will value their children less as human beings.

\section{Market Opponents' Argument}

The process of trying to hand-craft children by blending our genes with genes of sellers whose looks, talents (or race?) we like is dangerous for humanity and human society. We in the West attach too much importance to our genes. It would improve our humanity and our society

if we adopted children abandoned by others rather than trying to hand-craft birth children.

\section{TABLE 3: SELF-CONSTITUTION AS A PERSON}

\section{Basic Value}

Self-constitution as a person (not as an object)

\section{Market Proponents' Argument}

Adoptive parents who purchased their children love them and often have rescued them from a difficult, oppressive life, and more objectified life. There is no evidence that adopted children, however acquired, are treated in the aggregate as more commodified or objectified than those born in the traditional way.

\section{Market Opponents' Argument}

The sale and purchase of children treats children as objects (market commodities), undermining the development of a self-conception as a unique person. The market will likely differentiate between "better quality" and "worse quality" children by features of the "product" (e.g., eye colour, potential athletic ability, and the troublesome factor of race). Moreover, the sale of (some) children could adversely affect personhood of everyone (because we have all been children) if all children then conceive of themselves as commodities and wonder how much money they are worth. 


\section{FURTHER COMMENTS ON CONTESTED COMMODITIES}

Much has been written about baby-selling and other contested commodities, but I am not attempting a review here. Instead, I will confine my further comments to the two theorists I have mentioned.

Walzer seems to accept that freely contracted sales will not (at least prima facie) be morally reprehensible - though he perhaps would not go as far as to condone selling oneself into slavery with full cognizance and a range of other choices. ${ }^{36}$ The difficulty with a topic like baby-selling is that it is messy in the world: Many transactions are made between consenting adults, and many others are made between powerful would-be parents and poor and desperate birth parents. A detailed regulatory regime would be required to cope with this complexity.

Sandel wants to avoid this complexity by somehow arriving at a moral answer for each problematic "good." He believes that he does not need to investigate whether parties are doing trades with free choice on both sides, because the notion of free choice is separate from the notion of corruption, so it is irrelevant to his conclusion. Sandel's procedure is somehow to determine which goods have a moral value that would be (or is being) undermined by market trading. But all of the conflicting arguments I lay out in Tables 1-3 rest on moral value, so it is hard to arrive at any definite answer about which side should win. Moreover, it is hard to get the argument off the ground because it is hard to define the "good" in question. How would Sandel decide whether commissioned adoption is a different "good" from sale of a live child? How would he decide whether commissioned pregnancy and adoption with a contribution of genetic material by the purchaser(s) is a different "good" than commissioned adoption without that contribution?

36. Here we are led into the question of what constitutes coercion, because selling oneself into slavery may not seem like a voluntary choice, except in theory. I cannot explore the topic of coercion here, which, like many important philosophical topics, is deeply contested. The view of coercion that I favour depends on to what extent one thinks that the circumstances in which a choice is made render the choice coercive. In this view, coercion is present when someone puts a party to a choice to which he or she has a moral right not to be put. "Your money or your life" is a standard example. The victim is freely choosing to hand over his or her wallet to save one's life, yet many thinkers on the topic of coercion would say the victim is coerced because he or she has a moral background right not to be put to that choice. This theory is contentious, because one could posit that some situations we might call coercion are not important enough to rise to the level of moral right, or even posit that some coercion is morally justified. 
Sandel does not argue that all commodification is wrong. It is only wrong where it represents corruption. Otherwise the market society is not questioned. Sandel argues that whether on balance commodification represents corruption is a moral question, to be approached differently in each case. In addition to the difficulties I have already mentioned, this argument raises two questions: (1) how much commodification in society is "too much"?; and (2) to what extent (if any) is it an empirical question whether we have "too much" commodification in our social practices?

With regard to question 2, I cannot see what kind of "empirical" question that would be-I think it would not be answerable by taking a survey of people's beliefs. To see whether or not commodification of children, or some other "good," undermines self-constitution as a person, we need to know whether a commodified (objectified) self-conception can stably co-exist with a non-commodified (non-objectified) self-conception. Everything about the bodies of models and actors is commodified and translates into more or fewer dollars. Does this make them less of a person? It does enrich cosmetic surgeons; it encourages some medical students to go into that field instead of family medicine or gerontology. It does extend to high school graduation gifts of breast implants or nose jobs. Yet it seems a stretch to say that the customers of this industry are no longer persons.

With regard to question 1, what if we can both know the price (dollar value) of something and also know that the thing is priceless? What if commodified understandings of certain interactions can coexist with non-commodified understandings? I think of this situation as incomplete commodification. If incomplete commodification is stable and not always in danger of becoming complete commodification, it might be acceptably human. Incomplete commodification might mean talking Econ talk, for example, but not actually buying and selling contested commodities. That approach might have been true of Becker and Posner, though Posner did seem serious about setting up an adoption market. If the level of this kind of incompleteness in commodification is very robust, then we need not worry about turning into Econs. We will just have an Econ part of ourselves but it will not capture the whole.

Yet one may wonder why market understandings have seemed so powerful? Someone fully committed to the old-school Chicago view of rationality might say market understandings are powerful because they are correct: They best explain and order our world. Someone committed to Marxist critique might say that market understandings seem powerful because they "naturally" link up with the entrenched power structure of capitalism. Someone else might say that market 
understandings really do not seem so powerful now as they did in the 70s and 80 s, and we do not have to worry. Still another might say, market understandings have largely won out now. Our society is more marketized than ever but we should not worry because there is nothing we can do about it.

Which view is right? I left this question unanswered in my earlier research. ${ }^{37}$ It troubled me that many feminists were choosing the market prong of a dilemma-i.e. "I should be free to sell my baby for adoption if I want to"38_ without realizing even that there is a dilemma, though the dilemma is clearly shown in the opposing arguments I mentioned earlier. I remain committed to the idea that it is best to address these questions as dilemmas and try to see how they might be resolved. I remain committed to the idea that attempting to observe something that can be labelled "corruption" (or "freedom") in a particular practice is largely a dead end because the dilemmas remain.

\section{BOILERPLATE AND THE LIMITS OF CONTRACTUALIZATION}

Now I want to turn from baby-selling to boilerplate. Here I offer some thoughts on contractualization as it exists in the US today. I hasten to say that the situation in the US I describe does not prevail to the same extent in any other developed country. The progression of thought follows the pattern of reflection on propertization. Thinking about the limits of propertization led me, first, to examine how the basic rationale(s) for propertization do not read well on actual practices in the world, and then to consider the problem of commodification and the limits of markets (market-inalienability). Similarly, thinking about the limits on contractualization led me, first, to examine how the basic rationales for contract enforcement do not read well on actual practices in the world, and then to consider the problem of commodification and the limits of markets (market-inalienability). Market-inalienability is, after all, simply a prohibition on contracting with regard to certain goods or attributes, even with full consent. It is both a limit on propertization and a limit on contractualization, depending

37. See Radin, Contested Commodities, supra note 4, ch 7. These questions emerged more clearly as I thought further about the dilemmas of commodification in the contemporary world of gene technology and globalism. See Margaret Jane Radin, "Response: Persistent Perplexities" (2001) 11:3 Kennedy Inst of Ethics J 305; Margaret Jane Radin, "Cloning and Commodification” (2002) 53:5 Hastings L J 1123.

38. See e.g. Martha Ertman, "The Upside of Baby Markets" in Michele Bratcher Goodwin, ed, Baby Markets: Money and the New Politics of Creating Families (New York: Cambridge University Press, 2010) 23. 
on whether we focus on prohibition of selling something or prohibition on treating that thing as property.

\section{A. A PROBLEM IN THEORY-TO-WORLD FIT}

Standardized contracts-I should say "alleged contracts"-are causing a disconnect between the rationale for contract enforcement and how these contracts actually function in the world. This fissure in theory-to-world fit has burgeoned in the contemporary world of the digital networked environment and in the information society that this environment is creating. ${ }^{39}$ Before launching into this discussion, I must make clear that I am not addressing all standardized agreements or clauses. Standardized clauses or whole standardized agreements are often very useful and can be the result of bargaining to agreement about possessions that are in fact subject to private agreement.

Nevertheless, mass-market boilerplate, at least in the US, raises a question about the limits of contractualization because it has become an ever-increasing tool for massive rights deletion. By rights deletion, I mean clauses such as: waiver of the right to sue for negligence (exculpatory or exclusion clauses); waiver of the right to jury trial and aggregative relief (accomplished by mandatory pre-dispute arbitration clauses); and onerous forum selection clauses (undermining due process of law by declaring that legal remedies must be pursued in a jurisdiction far away from the injured party's home).

The basic facts about contractual ordering are fundamental to western systems of law and to civil society. In this fundamental understanding there are four entrenched basic premises: First, with few exceptions we accept that individuals ought to be able to express and enhance their autonomy to improve their situations in life, by trading with others on terms acceptable to themselves (some exceptions come to light when we consider market-inalienability in the context of propertization). Second, we realize that, in order for this system to work, human beings must follow through and keep valid contracts once made. Third, we realize that, given our human fallibilities, some contracts will be invalid for various reasons, such as coercion and deception; and some valid contracts will not be performed. Fourth, we therefore entrust to the state the power and duty both to police contracts for invalidity and to enforce performance (or grant the injured party damages as a substitute) where a party fails to perform a contract

39. I addressed the issue of theory-to-world fit in Margaret Jane Radin, "The Deformation of Contract in the Information Society," (2017) Oxf J Leg Stud gqx001 [Radin, "Deformation of Contract"]. 
that is valid. The state must refuse to enforce invalid contracts and it must enforce valid contracts.

When the state enforces a contract made by A and B, the state deprives A of an entitlement, something that legally belonged to her, and delivers that entitlement to $\mathrm{B}$. What prevents this from being an unjustified state redistribution of property rights? Thus, the question becomes: what acceptable theory (or theories) justifies the state in deciding when A and B have entered into a contract and when they have not; and when either A or B has breached a contract and when he or she has not? Contract theory is crucial to the legitimacy of contractual enforcement.

Basic contract theory has several branches: autonomy (freedom) theory, utilitarian theory, Aristotelian theory, and economic theory (a branch of utilitarian theory).$^{40}$ Each of these theories has at its root the assumption that people exercise freedom of choice when they enter into agreements (which the state will then enforce). Each of these theories also assumes that individuals are free and equal; and that individuals make choices for their own lives, and are not subjugated to others. How, if at all, do these theories of justification map onto our current practices of contractualization?

All prevalent theories require agreement. ${ }^{41}$ Two parties agree on an exchange. What does it take to bring about agreement? This is a disputed question, which I cannot elaborate here. Instead I will approach the issue from the other end: at least it is not hard to specify some varieties of circumstances that do not bring about agreement. Although a general theory of what constitutes agreement is not self-evident, without going into philosophical dilemmas and disputed premises, I think we can postulate that a person cannot be said to have agreed to something unless he or she at minimum — before agreement! — possesses a certain quantum of information about what he or she is agreeing to, and unless we can determine that he or she was not coerced or deceived.

40. See Radin, Boilerplate, supra note 4 at 55-72. There I offer a summary of the main theories of contract. I hope that chapter will prove useful for students of the law.

41. A number of prevalent theories base contract on promising rather than on agreement: two parties come together and promise each other to perform. See e.g. Charles Fried, Contract as Promise, 2nd ed (New York: Oxford University Press, 2015). There are debates in the philosophy of contract about whether one should take promising or agreement as basic. See e.g. Gregory Klass, George Letsas \& Prince Saprai, eds, Philosophical Foundations of Contract Law (New York: Oxford University Press, 2014). I do not mean to equate promising fully with agreement, but I think that theories based on promising tend to assume agreement as a background condition. Even if promise theorists would disagree with this, at any rate I think that relating the basis of contract to agreement does not lead to results that are not also reached by promise theorists, given similar intuitions about substantive outcomes. 
Yet when we come to the realm of contract law as it is practiced in the US with regard to "contracts of adhesion," some things seemed to be dubbed agreement just in order to be able to call a situation an enforceable contract. A free individual cannot validly be said to agree to have his or her freedom of choice engaged by the mere fact that a list of terms exists somewhere in his or her physical vicinity. Yet American law tends to the position that if someone had a reasonable opportunity to see a list of terms, that person is bound to those terms even if he or she did not actually see them. Nor can a free individual validly be said to agree to have his or her property or freedom of choice curtailed by a list of waivers that is revealed later, after he or she has already agreed to an exchange without seeing the rights deletion list. Yet US courts enforce pay-now-terms-later (PNTL) procedure as being contractual- the customer pays first, the merchant deposits the money and ships the goods, then boilerplate terms arrive with the goods. Helping convince courts to validate this procedure is a rather useless proviso that if recipients do not like the terms when they arrive, they may send back the product and get their money back.

I hasten to say that in the common law there is an "objective" theory of contract that does not require actual agreement, but only a situation that looks like agreement. This doctrine has been with us - that is, with jurisdictions that received the law of England - since the inception of the industrial era. It says that one party will be deemed to have accepted (agreed to) the proposal of the other party when the proposing party could reasonably believe that agreement to his or her offer was being signaled; that is, where behaviour of the offeree could be understood to have looked to the offeror like agreement. This theory probably functioned acceptably when all who entered into contracts were traders who knew each other, who were socialized into a particular practice in which it was feasible to know when agreement was being signaled. In today's world, this "objective" doctrine reveals a fissure in contract law-we say that real agreement is necessary to deprive someone of an entitlement, yet we also say that it is good enough if circumstances somehow look like real agreement happened.

Even though this "objective" doctrine survives, companies that deploy mass-market boilerplate designed specifically to conceal such things as overdraft fees and balloon payments should not be allowed to claim that they reasonably believe the recipients are actually agreeing. Moreover, the procedures such as reasonable opportunity to see a list of terms — or PNTL—that are today called agreement, are often problematic even under objective theory. If the state enforces such alleged agreements anyway, it takes property (money or other rights) from A and delivers it to $\mathrm{B}$ without justification, unless we find a better rationale- better theory-to-world fit-to justify such enforcement. 


\section{B. OTHER APPROACHES TO EVALUATION OF BOILERPLATE ENFORCEABILITY}

What better rationales might there be? It is not convincing to change the meaning of the word "agreement" by fiat (at least in the short run, though language is malleable in the longer run). Yet it does look as though US courts and boilerplate defenders are doing just that. Such devolution in the meaning of agreement is what I call normative degradation. ${ }^{42}$ Normative degradation would be Humpty Dumpty's solution: "'When $I$ use a word,' Humpty Dumpty said, in a rather scornful tone, 'it means just what I choose it to mean-neither more nor less."'43 Nor do I think it is acceptable to say that a rational person would agree to this set of unread fine print rights deletions, even if this particular person did not. ${ }^{44}$

A favourite substitute rationale for boilerplate enforcement, endorsed by many, can be paraphrased as "But-in our modern market society-we really need to have enforceable mass-market boilerplate!" ${ }^{5}$ It may turn out that need for enforceable mass-market standardized fine print turns out to be a good substitute rationale for enforcement in some instances. But that does not tell us that we should keep calling mass-market rights deletions contracts. The contractual rationale for taking a property right from $\mathrm{A}$ and giving it to $\mathrm{B}$ that currently exists in our system of government is actual (uncoerced and non-deceptive) agreement (with an asterisk for something that looks as if agreement took place). To justify proceeding under the substitute rationale of our need to defend mass-market boilerplate, it seems we need to find a legal niche other than contract.

Let us suppose we really do need to allow private firms to instigate and deploy some types of mass-market rights alterations in order to have efficient procedures for everyday transactions. Standardization does seem important (and perhaps indispensable) in many arenas. Standardized clauses or complete standardized sets of terms can be used for actual agreement. This method of agreement does not raise a concern about calling such a deal a contract.

Yet the argument that we need boilerplate-standardization of termscannot mean that we need to make each and every clause that firms dream up for their own advantage enforceable. We have to have some means of separating the sheep from the goats-just as we do when dealing with individually negotiated

42. See Radin, Boilerplate, supra note 4 at 19-32.

43. Lewis Carroll, Through the Looking-Glass, and What Alice Found There (New York: Random House, 1965) at 94.

44. I will come back to this argument later. See further discussion at Part III(C), below.

45. See e.g. Brian H Bix, "Contracts," in Franklin G Miller \& Alan Wertheimer, eds, The Ethics of Consent (New York: Oxford University Press, 2010) 251. 
contracts. Standardization is desirable when it is used for effecting transactions that benefit individuals and society; standardization is not desirable when it is imposed by firms to privatize an infrastructure of law that ought to remain public.

So, in the cases where mass-market boilerplate is deployed but the meaning of agreement seems at best distorted, we would need to seek other legal means by which mass-market boilerplate might be regulated. Some boilerplate could be acceptable even without calling on the concept of agreement, but some should be disallowed-particularly deceptive boilerplate that deprives a person of basic legal rights.

Such deceptive boilerplate could be assimilated to torts protecting persons from fraud and deception. If a firm is shown to have used terms on purpose to deceive people, or to take advantage of people's known heuristic biases (such as the belief that we will never miss a payment or have an overdraft), ${ }^{46}$ that firm should not be heard to claim that they believed recipients to be actually agreeing (the objective theory of contract should have no weight in such cases). It is not radical to switch legal adjudication of consumer claims against mass-market rights deletions from contract law to tort law. Over time legal doctrinal categories change. Warranty passed from contract to tort, for example. Tort also gathered up a lot of causes of action in the past, such as the law of master and servant. Tort may be a helpful way to judge the limits of enforceability of mass-market boilerplate.

Further, we could allow some level of boilerplate that we deemed not deceptive to be treated simply as part of the product being purchased. Here I partially agree with a certain type of economic theory put forward by Douglas Baird. ${ }^{47}$ He posits that both the boilerplate and the functional mechanisms of a product can be considered internal to the product, and will together determine its market price. I only partially agree with Baird, because not all markets will result in an appropriate price being set for all buyers. That depends, among other things, on whether the market can be segmented, and on the degree of information asymmetry between sellers and buyers and among buyers. ${ }^{48}$ Moreover, I only partially agree because some of those terms that are part of the product may be attempting to delete market-inalienable rights, as I will discuss shortly.

46. See Oren Bar-Gill, Seduction by Contract: Law, Economics, and Psychology in Consumer Markets (Great Britain: Oxford University Press, 2012) at 8-17.

47. "The Boilerplate Puzzle" (2006) 104:5 Mich L Rev 933, reprinted in Omri Ben-Shahr, ed, Boilerplate: The Foundation of Market Contracts (Cambridge: Cambridge University Press, 2007) 131. See also Douglas G Baird, Reconstructing Contracts (Cambridge: Harvard University Press, 2013) ch 8 at 123-46.

48. See the text accompanying notes 60-61. 
Even if terms-plus-functioning parts are one product, there is still such a thing as a defective product. So, this contract-as-product theory, which should now be called "composite product theory," is another way to lead us toward a tort-like theory of adjudicating the enforceability of boilerplate.

Even if the firm does not insist very strenuously that its fine print is a contract, its fine print can still make its product defective. Consider Facebook's Data Policy:

We store data for as long as it is necessary to provide products and services to you and others .... . When you delete your account, we delete things you have posted ... . Keep in mind that information that others have shared about you is not part of your account and will not be deleted. ${ }^{49}$

Facebook has gradually broadened its terms over time. Now many people have grown up with their entire lives on Facebook. They cannot delete their accounts without losing special memories. And even if they do delete their accounts, Facebook retains the right to market products to others using content that was shared. Facebook's terms are a good candidate to be seen as rendering Facebook a defective product.

In addition to considering tort-like limits on mass-market boilerplate deletions of recipients' legal rights, we should pay renewed attention to due process of law as another means of developing appropriate limits on suppression of the right to redress of grievances. In this regard, the work of Judith Resnik, a scholar of due process and procedural constitutional law, should be noted. ${ }^{50}$ Resnik recently analyzed the US Supreme Court's cases that re-interpreted the 1925 United States Federal Arbitration Act ${ }^{51}$ to give it ever wider applicability. She concluded that although this expansion has encouraged the "mass production of arbitration clauses" by firms that deploy these clauses in boilerplate with millions of consumers and employees, consumers and employees enter into arbitration extremely rarely. ${ }^{52}$ Resnik concludes that the Court's attempt to replace public dispute resolution (litigation) with private dispute resolution (arbitration) instead most frequently results in no dispute resolution.

What is wrong with using arbitration in consumer disputes? It is supposed to be cheaper and quicker- that is why companies like it. And, in theory, that is why consumers should like it, too. But (1) many arbitrators are repeat players for

49. Facebook, "Data Policy” (29 September 2016), online: <www.facebook.com/ full_data_use_policy>.

50. "Diffusing Disputes: The Public in the Private of Arbitration, the Private in Courts, and the Erasure of Rights" (2015) 124:8 Yale LJ 2804.

51. 9 USC $\$ \S 1-16,43$ Stat 883.

52. Resnik, supra note 50 at 2812. 
firms, and it is at least widely suspected that they rule in favour of the firm most of the time; ${ }^{53}$ (2) arbitration is private and secret, so if a firm were to lose a case of attempted waiver of rights to one consumer, it could still deploy the same waiver with every other consumer; (3) arbitration creates no precedent, so that even if consumer A wins an arbitration case and succeeds in disallowing a waiver, the firm can still deploy the same arbitration clause against consumers B through Z; and (4) as interpreted by the US Supreme Court, arbitration must be strictly by an individual against the firm, so aggregative actions are prohibited. That means that many injuries - those that depend on aggregative actions — simply cannot be remedied. The US Supreme Court in effect has said that this is just too bad. ${ }^{54}$ No wonder arbitration is rarely used by consumers and employees. ${ }^{55}$

In addition to urging courts to pay better attention to due process of law, we could consider taking this issue away from the courts, and regulating boilerplate similar to food labeling. We do not allow food purveyors simply to paste a label on a package saying that if it causes purchasers or their children to get sick, that is just too bad-the firm is not responsible. So why should we allow a nursing home or a daycare centre to exclude itself from liability for any and all harm it causes to our parents or our children? Yet many service providers deploy blanket clauses that exclude liability for all harms to patients or customers. ${ }^{56}$

53. See David Horton \& Andrea Cann Chandrasekher, "After the Revolution: An Empirical Study of Consumer Arbitration" (2015) 104:57 Geo LJ 57 at 124 (disputing earlier research claiming arbitrators are employed by firms and biased in their favour, but concluding that "high-level and super repeat-playing companies perform particularly well"). See also Resnik, supra note 50 at 2853 (describing how arbitration organizations are structured so that it is impossible for us to know and observe what they and their members are doing).

54. See American Express Co v Italian Colors Restaurant, 133 S Ct 2304 (2013),

Kagan J, dissenting.

55. See Resnik, supra note 50 . Note that I am considering here only arbitration clauses in mass-market deployments by firms with employees, consumers, and businesses in the position of consumers. International arbitration and arbitration between large firms of roughly equal negotiating power form a different subject. Arguably, it was these latter arbitrations that the US Federal Arbitration Act of 1925 was intended to serve, and not the wholesale use of arbitration to narrow or eliminate consumer remedies that the US Supreme Court has now interpreted that statute to cover.

56. Note that this rampant exculpation that is taking place in the US through boilerplate deployment relates to service providers not products. In the US, contracts for the sale of goods are covered by the Uniform Commercial Code (UCC), a model statute that every state has enacted (with some differences). The UCC provides that purported contractual exculpation for a seller's own negligence is prima facie unconscionable if it causes injury to a consumer, but there is no comparable law for services. See UCC ${ }^{\S} 2-719$ (2002). I must also note here, as many readers will be aware, that such exculpatory or exclusion clauses in consumer transactions are illegal in many countries. 
Added to the almost ubiquitous pre-dispute arbitration clauses that effectively waive class action rights, it seems that recipients are widely deprived of redress of grievances. Perhaps this is a cause for the polity itself to reestablish its unwaivable responsibility to provide for redress of grievances. ${ }^{57}$

\section{CODA: FLAWED ARGUMENTS IN DEFENCE OF BOILERPLATE}

This discussion would be incomplete, I fear, without responding to various defences for boilerplate endorsed by businesses and their supporters among law-and-economics writers. Although these arguments may explain why standardization of terms is often appropriate, I think they fail to justify mass-market boilerplate rights deletions across the board. Economics is supposed to evaluate markets one at a time, not make blanket assumptions. I have alluded earlier to some of these defences, but I will conclude this discussion by offering more about these defences of boilerplate rights deletions, dividing them into empirical and normative arguments.

The most common empirical argument runs as follows. Exculpatory clauses, forum selection clauses, and other rights deletions will allow the firm to save money. The firm will pass on these savings to consumers in lower prices. ${ }^{58}$ Consumers will value the lower prices more than they value their legal rights. To put this slightly more accurately, consumers will not value their legal rights at or above the difference between the price of the product or service with legal rights included versus the price without legal rights included. Therefore, boilerplate defenders say, the deprivations are efficient and justified.

What is wrong with this argument? It is probably true that the firm will save money for itself by depriving consumers of their legal rights (unless doing so starts to drive customers away, which it may well do when a large enough cohort of customers becomes aware of the practice). But it is not necessarily true that

57. As I write this, the US's Consumer Financial Protection Board (CFBC) is considering rules that would curtain arbitration clauses used against consumers and employees. See Consumer Financial Protection Board, "CFPB Proposes Prohibiting Mandatory Arbitration Clauses that Deny Groups of Consumers their Day in Court” (May 2016), online: <www. consumerfinance.gov/about-us/newsroom/consumer-financial-protection-bureau-proposesprohibiting-mandatory-arbitration-clauses-deny-groups-consumers-their-day-court>. The CPFB's position is politically precarious, however, because the current government is dominated by conservatives; the CPFB may lose its power to regulate arbitration clauses, or even be legislated out of existence.

58. Carnival Cruise Lines v Shute, 499 US 585 (1991) at para 594. This argument is said to "stand to reason," with absolutely no documentation or reasoning whatsoever. Unfortunately, US federal courts have not only followed but rather expanded on the holding of this case. See e.g. ProCD v Zeidenberg, 86 F.3d 1447 (7th Cir 1996). 
the firm will pass on its savings and charge customers that much less. Instead, the firm may just keep the money. Whether or how much savings and charges (such as taxes) are passed on is a difficult topic in economics. At least whether or not passing on occurs, and to what degree, depends upon various factors that differ with each market-whether or not the market is competitive, whether or not there are close substitutes for the product, and particularly the degree of understanding or information possessed by buyers of the product. Therefore, at minimum, this argument must be evaluated market by market, and cannot be valid as a general matter. Contrary to the US Supreme Court, it cannot just "stand to reason." 59

Moreover, it is not appropriate to consider consumers' low ex ante subjective valuation of their legal rights as the proper amount to trade off against the supposed lower prices to be offered by the firm. As I argued in Part III(B) above, legal rights of redress are not salient to individuals before they are needed. The fact that many consumers do not subjectively place much value on their legal rights before a situation arises in which the rights are needed does not mean that the legal rights are not valuable to each and every consumer. It is not true that we must subjectively understand and monetarily value legal rights for those rights to be valuable to us as individuals. To think that idea is valid reflects a naïve embrace of old-school Chicago law and economics.

A more sophisticated variant of the blanket empirical argument is the idea that the service or physical product should be combined with the boilerplate and treated as one object, which I discussed earlier as the composite product theory. The argument here is that even if most consumers do not know what is going on with the boilerplate and therefore do not know to what extent they value their legal rights, there will be some subset of consumers who are "savvy" about this-who have enough information to know what value to attach to the service or physical product itself, combined with what value to attach to the rights that come with it. This theory, in other words, divides consumers into a large component of low-information consumers and a small component of high-information consumers. The "savvy" subset will set the market price, and all the other "non-savvy" consumers will be able to take advantage of the same price (assuming, of course, that the seller cannot segment the market to charge more to the non-savvy people). Law-and-economics scholars who follow the savvy-subset theory indeed say that the non-savvy people are benefiting from cross-subsidization on account of the savvy people-that is, that they are benefiting from the information known by others.

59. Carnival Cruise, ibid. 
There are several difficulties with this savvy consumer subset theory, owing to the fact that economics is considered an empirical social science. The argument is not generalizable. We cannot assume that each and every market-or a subset large enough to validate the argument (whatever that would be)-is competitive. We cannot assume that each and every market has the proper amount of knowledge in the proper number of consumers and the proper level of difficulty of market-segmentation. ${ }^{60}$ Even in a competitive market, if all recipients have low information about product quality (and here product quality includes accompanying legal rights), then the market can result in a "lemons equilibrium" ${ }^{11}$ - that is, a race to the bottom. To stay competitive, all firms will have to offer their worst contract and the recipients will not know that the better contract would be more valuable to them.

Turning to normative difficulties with these attempts to defend mass-market rights deletions, let us assume that people mean to sell off their legal rights for lower prices, and let us even assume that the prices would actually be lower. If people can routinely sell off their legal rights, that establishes a market in legal rights. It is true that many legal rights are saleable in markets: fungible property rights and individual labour (subject to regulation that establishes limits). But, as I will consider briefly below, basic legal rights- those that we hold as members of a civil society - should not be treated as routine commodities. That is, they are market-inalienable, at least in situations where deletions are attempted on a mass-market basis.

The vast majority of people cannot subjectively value legal rights before they need them. Human judgment is inherently faulty in this respect. So, what if people might routinely sell off their legal rights because they are unable to realize their value subjectively before something bad happens and they need those rights? Prevention of this kind of result can be characterized as a reason why we (in the traditional metaphor) exit the state of nature and give to the state the responsibility of sustaining a system of redress of grievances. Preventing this kind of result, in other words, can undergird the case for market-inalienability.

But going further, some defences of boilerplate rights deletions say that even if consumers cannot be said to be actually doing anything — perhaps because they

60. The "savvy subset" conjecture has recently been investigated empirically in a likely market (software) and found to be invalid there. See Yannis Bakos, Florencia Marotta-Wurgler \&

David R Trossen, "Does Anyone Read the Fine Print? Consumer Attention to Standard Form Contracts" (2014) 43:1 J Leg Stud 1 at 2.

61. George A Akerlof, “The Market for 'Lemons': Quality Uncertainty and the Market Mechanism” (1970) 84:3 Q J Econ 488. 
do not know anything about legal rights-we should nevertheless understand them to be hypothetically consenting. Why? Presumably because that would be efficient and therefore rational for the consumers—so it seems the argument runs. It is hard to see how the proponent of such an argument would know what might be efficient and rational, but perhaps easier to imagine for those who are thinking of Econs, not Humans. But even if consumers could rightly be held to have consented through such a hypothetical process, the question of market-inalienability would still remain; that is, the question whether such consent would be invalid because individuals cannot trade off these rights for money.

Finally, there is a defence in which consent or hypothetical consent just drops out. In this version, it is efficient—so it is argued-for firms to delete legal rights in return for the-allegedly_-passed-on savings. In this version, there is no agreement or pretense of agreement, so, as proponents of this argument sometimes fail to realize, we are outside the realm of contract, or alleged contract. In this scenario, even assuming that savings are really passed on, in just the right amount, consumers' property-rule entitlements are being massively condemned by firms and turned into liability-rule entitlements under firms' control. ${ }^{62}$ Worse, it might even be argued by those who accept the Kaldor-Hicks version of efficiency, ${ }^{63}$ that the winners (the firms) would not have to compensate the losers (the consumers) if the aggregate gain to the firms outweighed the aggregate loss to the consumers. Under that argument, the firm can save money by forcing its customers to waive their legal rights but not be expected to pass on the savings in the form of lower prices.

To repeat: I do not argue that all boilerplate is wrong. Standardization in some circumstances may be a desirable procedure, even an indispensable procedure. I have not offered a fleshed-out treatment of what those circumstances might be. Instead, my argument is directed toward trying to ask the right questions about mass-market boilerplate as it is being deployed to cancel legal rights of redress.

62. A property rule entitlement is one according to which the holder has a right to choose whether or not to sell, and at what price. A liability-rule entitlement is one that another entity - a court or the government - can cancel if compensation is paid. CfCalabresi \& Melamed, "Property Rules, Liability Rules," supra note 10.

63. Kaldor-Hicks efficiency is named for Nicholas Kaldor and John Hicks, who theorized that a new resource allocation would be more efficient than the original resource allocation if those who are winners (better off) could hypothetically compensate the losers (worse off), even if the compensation does not take place. See Nicholas Kaldor, "Welfare Propositions in Economics and Interpersonal Comparisons of Utility" (1939) 49:195 Econ J 549; John Hicks, "The Foundations of Welfare Economics” (1939) 49:196 Econ J 696. 
These questions led to one species of market-inalienability, thus one take on the limits of propertization and contractualization.

\section{THE RULE OF LAW AND MASS-MARKET RIGHTS DELETIONS}

Finally, I come briefly to the effect of mass-market boilerplate rights deletions on the Rule of Law. Here consideration of the Rule of Law intertwines with the issue of market-inalienability. The Rule of Law is a contested concept, and I shall not here attempt to lay out and examine various versions of its precepts. I sometimes boil down the major precepts as follows: A state can be described as holding to the Rule of Law if at minimum it has laws (1) whose commands are knowable and (2) doable by human beings, (3) whose results are beneficial to human beings, and (4) whose implementation abides by equality before the law. Some writers on the Rule of Law include in its precepts more specific constitutional provisions of western democracies. ${ }^{64}$

Whatever the full panoply of principles and precepts we think the Rule of Law contains, it must be true that we should understand humans and their administrative machinery to commit errors from time to time. Thus, it must be true that rights affirmed and protected by the state must have remedies available to subjects in case the rights are transgressed. In my view, this means, among other things, that the background rules of the institutions of property and contract-including the limits of property and contract, and including remedies in property, tort, and contract law-must be maintained and properly enforced by government. That is, the rules of the background legal infrastructure must remain substantially within the care of the polity. The background rules may be changed by democratic action, and we expect them to evolve over time. But powerful firms should not be able to change the rules of the background legal infrastructure of the polity whenever they wish by a simple expedient such as deployment of boilerplate.

Earlier in my research I approached market-inalienability from the perspective of property, and here, as I did later in my research, I approach it from the perspective of contract. The boilerplate delivered to a consumer presumably could not say, for example, "this contract is only enforceable by the firm, not by the recipient." At least it should not say that, and if it does say that, it should not

64. In an article published in 1989, I divided conceptions of the Rule of Law into roughly two main strands, instrumental and substantive, each with sub-strands. Margaret Jane Radin, "Reconsidering the Rule of Law" (1989) 69:4 BUL Rev 781. 
be enforceable. It should not be enforceable because it would alter the background structure of contract in which parties are equally able to enforce contracts. Yet by saying that the firm may modify the "contract" however and whenever it wants, or that recipients' only remedy is arbitration (before arbitrators chosen by the firm and indebted to the firm for their jobs), or that recipients' only remedy is in a faraway place or sooner than the statute of limitations would have allowed, the firms are effectively engaging in privatization of the legal infrastructure of contracts. All of these privatization strategies are now occurring in the US on a widespread basis. By undermining the feasibility of remedy, firms that deploy boilerplate rights deletions are not just engaged in privatization, they are actually undermining the infrastructure that makes private law function. They may ultimately undermine their own ability to rely on contracts, not just the ability of their customers to do so.

Which rights are crucial to maintaining the infrastructure that makes private law function? How can we determine which rights should be permanently in the care of the polity? To say the least, the questions invite debate. But the questions will place debate where it ought to be. We should be arguing about which rights must remain in the care of the polity rather than being subject to mass-market waiver. Such argument should take primacy over continually arguing about whether clicking "I agree" without reading the fine print does or does not amount to consent, and thereby is or is not a binding contract. In other words, there is an important prior question: There must be some rights that cannot be waived by individuals on a massive basis, even if consent is present. ${ }^{65}$

Even Econs probably would recognize that rules to solve a collective action problem must remain in the care of the polity. ${ }^{66}$ For Humans I suggest that in addition the following characteristics may help identify some rights that must remain in the care of the polity and not be subject to mass-market waiver by individuals: (1) the rights are important to collective well-being, or indeed are

65. In this respect I agree with Michael Sandel: even with full consent of both parties, there are some trades that should be disallowed. See Part II(B)(2), above, for further discussion. Sandel did not focus on democratic degradation, however, and I believe trades resulting in democratic degradation are an important category of trades that should be disallowed in a polity that adheres to the Rule of Law.

66. Margaret Jane Radin, "The Fiduciary State and Private Ordering," in Paul B Miller \& Andrew S Gold, eds, Contract, Status, and Fiduciary Law (Oxford: Oxford University Press, 2017) 315. 
constitutive of civil society; (2) the purported waiver is widespread; and (3) the rights are not salient for individuals. ${ }^{67}$

What rights are important to collective well-being or constitutive of civil society? Without attempting to address this question in general, I think we can begin by saying that at least some necessary background rights relate to preservation of civil society itself. That is, some necessary background rights must exist in order to avoid lapsing into a condition akin to the state of nature-at least as regards those whose rights are deleted. ${ }^{68}$ Necessary background rights include rights to be free from harm to one's person or property, or indeed to one's basic freedom of action, either caused by the state or caused through the intent or fault of others. ${ }^{69}$

Of particular concern with regard to threatening these necessary background rights is the gathering trend in the US that allows boilerplate to waive liability for harm caused by negligence. A typical clause of this kind, which a parent was asked to sign in order for a child to attend a birthday party at a children's recreational facility, reads as follows:

The undersigned agrees to defend, indemnify, and hold harmless [this facility], its officers, managers, members, employees, servants, agents and coaches/instructors and their successors and assigns from and against all legal liability, claims, suits, damages, losses, and expenses, including attorneys' fees, threatened or incurred, and arising from the child's participation, or from any cause whatsoever.

Unless a society adopts some other method of compensation and deterrence, it is important not to allow the basic right to be free of injury from others' negligence to degenerate into a default rule routinely cancelled by boilerplate. Unfortunately, this concern is not merely theoretical, as a number of states in the US are now holding that people can waive their right to remedy for negligently inflicted harm..$^{70}$ Some are holding that people can waive the rights of their

67. See Radin, Boilerplate, supra note 4 at 37-40; Radin, "A Threat to the Rule of Law," supra note 30; Margaret Jane Radin, "Access to Justice and Abuses of Contract" (2016) 33:2 Windsor YB Access Just 177.

68. I think of this condition as quasi-anarchy; that is, a state of nature for the boilerplate recipient but not for the firm that imposes it. See Radin, "A Threat to the Rule of Law," supra note 30.

69. Of course, in situations of actual agreements between parties equal in negotiating power, one party may take on liability, and take upon itself the task of purchasing insurance (or that party might choose to self-insure). But this is not the reasoning applicable to mass-market boilerplate deployed against consumers. There is a serious problem in theory-to-world "fit" here with mass-market boilerplate rights deletion, but not with agreements between parties of equal negotiating power.

70. See e.g. Hall v Sinclair Refining Co, 242 NC 707, 709, 89 SE2d 396, 397 (1955). 
children, as well. ${ }^{71}$ Remedies for injuries caused by gross negligence, recklessness, and intentional harm should a fortiori not be waivable. So far courts have not gone beyond enforcing exculpation for a firm's own negligence. Many of the clauses in use pretend to waive everything ("from any cause whatsoever"). Perhaps they deter suits by recipients among the small minority that reads them-though activism on behalf of consumers may succeed in making consumers aware of these clauses and their effect without having to read them. More significant, perhaps they deter those non-readers who consult a lawyer, because the lawyer will inform such a client that there is at least serious trouble to be overcome because of the exculpatory clause.

Now that we (or at least most of us) understand that Humans are not Econs, that Humans are not rational in the sense imagined by old-school Chicago economics, the problem of heuristic bias on the part of Human recipients must be considered. In particular, rights-deletion clauses tend not to be salient to an individual before he or she needs to exercise the rights. An individual about to click "I agree" does not readily consider whether he or she will ever need any redress of grievances. Individuals do not consider whether they might need to be part of a class action lawsuit against a firm with whom they are dealing. They are likely to think that serious harms happen to other people. And indeed, serious harms most often do befall others - though into each life some rain must fall. Serious harms caused by firms we deal with do happen to some unlucky people some of the time, and that is one reason why the rights dealing with redress are needed for all of us. Our rights of redress are not salient to us before we need them. Our inability to protect such rights against cancellation before we need them explains why they must be considered to be permanently in the care of the polity; hence market-inalienable. That is, the fact that rights that undergird civil society as a whole are usually not salient to individuals underscores the point that such rights, though couched as attaching to individuals, should not be waivable by individuals. ${ }^{72}$

At a certain point, when we have millions of people without effective redress of grievances, we are not a society that observes the Rule of Law. Moreover, we are

71. See Colo Rev Stat ${ }^{\S} 13-22-107$ (2012); Kelly v United States, 809 F Supp 2d 429 (EDNC 2011); BJ's Wholesale Club, Inc v Rosen, 80 A.3d 345 (Md 2013).

72. At least, not by means of mass-market boilerplate. Whether or not boilerplate is deployed in a mass-market way seems significant at least when considering the Rule of Law, because the Rule of Law is a guide to practice in keeping with certain ideals; it is not a theoretical zero-sum game. An isolated single instance of wrongful waiver, though wrongful, would not necessarily undermine the Rule of Law because "fit" with an ideal of justice need not be perfect. 
not observing equality before the law when one segment of society still possesses important rights that the other segment has lost. Rights important to the Rule of Law should not be cancellable by mass-market boilerplate, but should remain in the care of the polity; that is, these rights should be market-inalienable. Further thought and debate is needed, about which rights these are, and when (under what circumstances) they must be non-waivable. For now I have considered that at least mass-market waivers of basic constitutional and remedial rights by means of boilerplate should be disallowed.

\section{CONCLUSION}

In a sense, this article is a memoir. I have taken the opportunity, generously offered by the Osgoode Hall Law \& Markets Symposium: Regulating Controversial Exchange, to review and reconsider some of my research in property theory and contract theory. One primary aim of my research-in the context of how theories of property or contract are (or are not) coherent with moral commitments and with legal and social practice-was to provide pathways for understanding the significance of market-inalienability. Market-inalienability is a procedure for maintaining rights that should be permanently in the care of the polity.

Much has changed in the time since I began writing about market-inalienability in the latter 1980s. At that time, it was unusual (and perhaps unheard of) to talk about commodification in a law review article, or in legal scholarship generally (the editors at Harvard University Press would not accept Commodification as the title of my 1996 book, and called it Contested Commodities instead). Today it is as acceptable to talk about and study commodification as any other subject of legal and social theory and practice, and, as demonstrated by the Symposium of which this memoir is a part, there are many scholars observing and writing about controversial markets, from many points of view. Commodification has not gone unnoticed, at least.

Perhaps that is an indication that markets involving trade in significant human capacities and indicia of personhood can co-exist with an understanding that such capacities and indicia ought not to be fully salable. Yet, it does seem that commodification of essential human attributes has been on the rise. Today controversial markets are international in scope, and the injustice involved in blaming sellers in poor countries for selling their body parts or their children to buyers from rich countries has not gone away. At the same time, however, today there are more writers who defend sellers without signing on to the thoroughgoing commitment to fungibility of value and market rhetoric characteristic of old 
school Chicago law and economics. Some readers of my memoir may think that the questions that bothered me in the mid-90s are resolved: we can all be part Human and part Econ. Others may think that commodification has proceeded apace and there is no going back to a less commodified time. For me the dilemmas I struggled with in my research remain.

Meanwhile, at least in developed countries, we have become more and more members of an information society. Many of the changes that have already taken place and are now taking place, such as replacement of human workers with robots, and replacement of state supervision of contracts with "self-enforcing algorithmic contracts" were not well predicted three decades ago (at least not by law professors). It remains to be seen what the maturing of the information society will ultimately mean for human personhood and for economics, psychology, and sociology. There is no doubt that the information society can have many beneficial effects, and in any case seems here to stay.

In the present day, which is perhaps a transition period, we are seeing a great many efforts to turn toward computer-implemented transactions, such as "self-enforcing algorithmic contracts," and away from transactions that are actually subject to the law of contracts. In my recent work on boilerplate I have touched the tip of the iceberg here, by noting that shifting of entitlements between parties by machines, which I call "machine rule," goes against the Rule of Law because it cuts out the backdrop of the state's supervision of contracts, the infrastructure of legality. ${ }^{73}$ Will the state in the information society be willing and able to reestablish its control of the background infrastructure of legality? Or will the privatization of rights and the control by profit-maximizing firms that worried me with mass-market boilerplate be brought to fruition with machine rule? I do not have a prediction to offer. I can only hope that scholars will continue to explore and understand the importance of legal infrastructure and the role of the polity in undergirding and enforcing the Rule of Law.

73. Radin, "Deformation of Contract," supra note 39. 